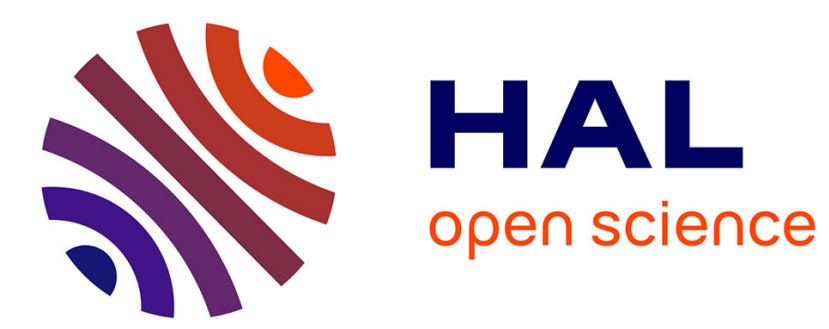

\title{
Critical review of an e-learning tool
}

Barbara Szafrajzen, Karen Ferreira-Meyers

\section{To cite this version:}

Barbara Szafrajzen, Karen Ferreira-Meyers. Critical review of an e-learning tool. Matteo Stocchetti. Media and Education in the Digital Age: Concepts, Assessments, Subversions, Peter Lang, pp.149-165, 2014, 978-3-653-98642-6. hal-03156634

\section{HAL Id: hal-03156634 https://hal.science/hal-03156634}

Submitted on 2 Mar 2021

HAL is a multi-disciplinary open access archive for the deposit and dissemination of scientific research documents, whether they are published or not. The documents may come from teaching and research institutions in France or abroad, or from public or private research centers.
L'archive ouverte pluridisciplinaire HAL, est destinée au dépôt et à la diffusion de documents scientifiques de niveau recherche, publiés ou non, émanant des établissements d'enseignement et de recherche français ou étrangers, des laboratoires publics ou privés. 


\title{
Critical review of an e-learning tool
}

\section{Barbara Szafrajzen \& Karen Ferreira-Meyers}

\begin{abstract}
The article is based on a recent doctoral research in communication and information sciences which set out to compare two teaching methods (the same training given in a face-to-face setting and at a distance) in order to analyze and understand the influence of a technological tool (Szafrajzen, 2010). It attempts to establish a critical assessment of elearning, with respect to actual practices and actors' "points of view in a given situation" (Parsons, Schütz, 1978) of learning. For this, the research tries to highlight the meanings for the actors, meanings that are the key to their understanding and thus learning (Depover, Giordana and Marton, 1998). This study allows us to understand and analyze a few of the meaningful learning experiences of e-learning education students (3rd year Bachelor's Degree), hosted by a university in the south of France.
\end{abstract}

Keywords: Communicative study, distance learning, meaningful learning experiences, constructivism, community of practice.

\section{Introduction}

The place of communication and information technology in the current academic landscape is indisputable. E-learning and e-education has grown significantly in many universities, thanks to various factors (technological, pedagogical, psychosocial, cognitive, socio-economic, etc.). The integration of computer science tools in this new type of learning device (Choplin, 2002) has led to learners greatly modifying their learning experiences in a meaningful way, forcing the university to adapt to these changes. In addition, new problems inherent to the students' needs to "tame distance" (Jacquinot, 1993) have thus emerged.

In human and social sciences, many researchers have been interested in cyberspace, especially the emergence of an "ideology" community within it. In the early 1990s, science education literature concerned with models of collaborative work and distributed cognition is already abundant (Resnic, Levine, Teasley, 1991). In anthropology, research on collective intelligence and virtual agora offers, at the same time, a cyberspace anthropology as "public service" and "collective intelligence" (Levy, 1994). More recently in sociology the work of Maria C. Papadakis summarizes the main characteristics specific to these communities (Papadakis, 2003).

To understand the place of ICT in learning environments, we base our comments on some of the meaningful learning experiences from the concrete example of an e-learning education program in communication and information 
sciences ${ }^{1}$. We investigate how a communicative study helps to understand and analyze meaningful learning experiences of learners in this type of training.

To understand how the social actors, specifically the learners, co-construct their collective learning reality in their e-learning environment, we choose to first adopt an epistemological position which follows a "constructivist convention" (Le Moigne, 2003). The methodology involves two main qualitative methods of data analysis: the method of qualitative content analysis and the method of qualitative systemic analysis (Mucchielli, 2004). In a third step, we describe the device as well as the e-learning learning situation. Finally, we look at how students bridge the distance through the emergence of a learning community.

\section{The epistemological framework}

We wish to determine the meaning that each learner gives to his or her learning situation $^{2}$. For this, we make our first assumption ${ }^{3}$ that meaning is only constructed in situations and in interactions with the learning device (whether human entities, material and/or ideational). Situational semiotics focuses on the idea of emerging meaning in situations and interactions. The genesis of shared meaning is the issue at the heart of this research method. Moving away from compartmentalised representations which the actors have of their situation, this method offers a new vision of a much broader and more complex situation. We also assume that there are collective learning situations within this distance elearning learning ${ }^{4}$. To understand how the learners co-construct their collective learning reality, we choose to adopt the constructivist epistemological position (Le Moigne, 2003).

1 This article reiterates and elaborates some of the results obtained in one of the authors' recent doctoral research in communication and information sciences, entitled «Etude communicationnelle de deux dispositifs d'apprentissage mis en place au sein d'un même département universitaire. Le cas de la Licence en sciences de l'information et de la communication », PhD obtained on 10 December 2010 in Montpellier (France).

2 We understand the term "learning" in the sense of Etienne Wenger: Learning has a social dimension and manifests itself in social interactions of actors engaged in a common practice (Wenger, 1998).

We seek to confirm these assumptions in our field study.

As part of the doctoral research, we tried to explore some meaningful learning experiences of students in distance education. Our study also observed the emergence of a learning community born of a collective approach to knowledge sharing. However, we do not want to consider construction and sharing of knowledge in a limited way, namely as an exclusively collective dynamic. This is why we specify that we are interested in players (specifically learners) situations and interactions with their learning device, so that they understand the representations of their distance learning. 
Jean-Louis Le Moigne proposes the term "constructivist convention" to scientific communities: "In presenting itself as an alternative convention, constructivism also reveals the conventional positivist epistemologies"(ibid.: 61). The term "constructivist convention" also highlights the possible nuances in the different ways of understanding the constructivist posture and "allows a 'generally accepted' representation of "the classic or institutional epistemological convention" (op. cit.: 45).

Within this convention, learning is seen as an active mechanism; the learner seeks the meaning of his action with regard to the meaning ${ }^{5}$ that can be grafted to this action. To better understand this, our approach is based on constructivism as described by Alex Mucchielli (Mucchielli, 2003). This author postulates that knowledge is constructed, unfinished, plausible, suitable and contingent, purpose-oriented, dependent on the actions and experiences of the knowing subjects, structured by the process of knowledge while also and at the same time structuring it, and, finally, forged in and through the interaction of the knower with the world (Mucchielli, 2004). We take the term constructivism to the extent that we construct the meaning given by the actors in a situation through a contextualization of their words and actions, without reading grids or a priori considerations of data. It is therefore a progressive construction of signification. Other authors, such as Peter Ludwig Berger and Thomas Luckman (2006) also developed the idea of collective construction of social reality. "Construction" then is only the reality constructed by those involved in the situation. Therefore, a constructivist learning device would be a device offering construction of knowledge routes to each of the actors present in the learning situation. The search for meaning is therefore based on items deemed relevant and interesting for the actors. Then, taking the precepts of Paul Watzlawick, we can say that the actors then produce "secondary realities" (Watzlawick).

Knowledge is not an acquired given but rather something that is constructed. Thus, the researchers consider that reality in itself does not exist; there are only representations co-constructed by the actors: "Under this assumption the path of knowledge does not exist a priori, it is constructed along the way" (Thiétart, 2007: 24). Therefore, we choose to think of learning situation as built by the actors while present. In this sense, we try to find the meanings they give from their point of view; this is precisely why we speak of

5 Etienne Wenger speaks of "negotiation of meaning" to define the concepts of community of practice (Wenger, 1998). For him, the negotiation of meaning during the action which is taking place is the most relevant stage to analyze the collective practices. It is precisely within this idea, mentioned by Etienne Wenger, of negotiation of meaning that we situate our discussion, or even "sense-making" (creative meaning) as Karl Weick understands it: The dynamic process of creating sense in construction (Weick, 1995). 
"point of view of the actors in a situation", to borrow a phrase previously used by Talcott Parsons and Alfred Schütz (Parsons, Schütz, 1978).

What interests us here are the points of view of individual and collective actors in educational systems: their projections, their visions, in other words what they think, what they are, or what they claim to do. It is through different questionnaires but also simple participant observations that we focus on the vision they have of their learning, whether classroom based or at a distance. Indeed, to highlight the views of stakeholders, also equates to bringing out the meanings for the actor, "meanings" that are key to understanding and therefore to learning (Depover, Giordana and Marton, 1998).

In addition, each player has its mode of operation, method of thinking, experience, knowledge, and it is within social interaction that s/he will give them meaning. In this regard, Anne-Nelly Perret-Clermont considers that these are "[...] interactions that require the subject to coordinate its actions with those of others, as the result of a process of decentering that engages in a conflict between his point of view and that of its partners" (Perret-Clermont, 1979: 136). In this sense, the idea of socio-cognitive conflict refers to "cognitive restructuring" (ibid.) and implies the existence of different points of view which have to be taken into consideration.

The construction of knowledge is an iterative phenomenon as it occurs gradually, individually, but also collectively (we will also discuss collective construction of meaning in this article). This idea echoes that of recursion loops; a role player from the situation's point of view is ultimately the result of a constant interaction between the individual, the surrounding environment, and all other involved individuals.

In view of this "constructivist agreement", knowledge is regarded as inherent in human constructions. Therefore, a learning device, whether face-toface or at a distance, offers knowledge construction that the learner should own (so we also position ourselves in the idea of action, or the learner taken as an actor of his learning). Many educationalists, also in pedagogics, studied and demonstrated the importance of distinguishing the terms "knowledge" and "expertise". To understand the distinction we make between these two terms, we take the two definitions recently proposed by Renald Legendre. According to him, knowledge includes "facts, information, concepts, principles we acquire through study and experience" (Legendre, 2005: 274), while expertise is "to have in mind a set of information, ideas and data, which are knowledge of a field of activity, an object or a person" (ibid.). These two definitions correspond to our point of view and it is precisely because we are interested in the construction of this knowledge that we prefer to invoke the term knowledge.

Following these epistemological precepts we chose to do our fieldwork first, anchoring our methodology on a qualitative approach. 


\section{The methodological framework from a qualitative approach}

Our research problem leads us to construct a methodology in terms of practices and perspectives of actors in a given situation. We formulate our problem statement as follows: "How can a communications study allow us to understand and analyze meaningful learning experiences of students in a distance e-learning set-up?". This statement highlights our commitment to focus on the construction of knowledge among students. However, the research problem can be considered in three parts: first, we seek to understand the meaning given by the role players of their learning situation. This understanding will enable us, secondly, to understand the functioning of e-learning. Finally, through the understanding of how this works, we question the idea of sharing knowledge in a process that we see as collective and shared by the community of learners.

To avoid the "critique of the arbitrary choice of data" (Matthey, 2003: 39) collected and analyzed, we choose to use methodological triangulation, which refers to crossing different data gathering techniques, so as to "improve the validity of the proposed results"6 (Mangenot, 2006).

We therefore prefer a qualitative approach bringing together four main data collection techniques: observations (made during monthly face-to-face meetings), interviews (centered non-directive and active directive interviews), keeping of a diary (technique used throughout our study), as well as the analysis of several conversations on the discussion forum. This qualitative methodological approach led us to mobilize two main methods of data analysis: the method of qualitative content analysis and the method of qualitative systemic analysis (Mucchielli, 2004).

The method of qualitative content analysis, also called method of categorization, enabled us to deal with three main themes with our learners (having induced the questions during the interviews, with various sub-categories such as the relationship system, the organization of work, etc.): the learners' profile, their meaningful learning experiences and their views on their learning paths. After completing each interview, we inserted all the comments gathered in a reading grid. We then compared each of these opinions, in order to bring out differences, recurrences, etc. (Szafrajzen, 2010).

The second method is called the method of qualitative systemic analysis. By combining conventional techniques (interview and observation, thematic content analysis and graphical representation), the so-called systemic qualitative analysis method wishes to understand and analyze the meaning given by role

6 We understand the concept of practice (just like learning) within the meaning proposed by Etienne Wenger, namely in terms of a social approach. 
players in a given situation. Complemented by an analytical commentary showing the circular causalities, the method also highlights the system's logic (implicit and latent rules directing the role players) and "game rules" of the present role players, or repetitive scenarios (Mucchielli 2006). It is to highlight the encompassing system, that is to say, the environment for a pre-defined framework and then to understand the existential and secondary benefits that role players take from their interactions.

In line with the comprehensive approach, the qualitative systemic method adds six reading and interpretation principles of any communication:

- The systemic principle: a phenomenon has to be analyzed in conjunction with a range of other phenomena;

- The framework principle asking the role players to look at and define the environment of any phenomenon;

- The principle of the primacy of systemic context: a phenomenon exists and has meaning only in conjunction with the given context created by the system itself;

- The principle of circular causality: a chain of cause and effect acting through feedback to enhance or inhibit the mechanism;

- The homeostatic principle: a phenomenon system develops an internal force that holds it together;

- The principle of emergence of paradoxes: "in a system, each phenomenon is both autonomous and forced, organized and organizing, informing and informed" (Mucchielli, 2004).

It is in line with the work of the school of Palo Alto in the sense that the researcher highlights the significance of the interaction between the different actors. This method interprets the operation of communicational phenomena by attempting to explain the meanings of the exchanges between the different actors involved in the situation (Mucchielli, 2004). Alex Mucchielli (2004) affirms that it is qualitative in that it allows the emergence of the meanings of the exchanges in a communicative system. It is also scientific as it is the researcher with his/her epistemological intellectual, analytical and methodological referents who makes the meanings emerge. Finally, it is part of constructivist paradigm insofar as it highlights the construction of meaning in emerging situations: "The systemic theory of communication is a constructivist theory of the meaning of communications (and of the remainder of communicational phenomena)" (Mucchielli, 2006: 54-55).

Having clarified our epistemological and methodological coordinates, we now propose to introduce e-learning in the field of communication and information sciences. 


\section{E-learning in communication and information sciences}

The definitions stemming from the learning device typology now distinguish "enriched face-to-face" situations: situations of education or training in which there is multimedia usage in the presence of students, and "enhanced face-to-face" situations: teaching or training situations carried out upstream and/or downstream at a distance with a face-to-face component. They must also be distinguished from so-called mixed situations (or blended learning), situations where education or training activities take place outside the physical presence of the teacher and can lead to "light", "reduced" or "almost nonexistent" face-to-face components.

This plurality of denominations supports all our research, whether bibliographical or web-related, having made us encounter a large amount of names to define distance education, depending on the amount of face-to-face and distance: embedded learning, distance learning, blended learning, full e learning, mix learning, etc.

According to some authors, we have now arrived in the era of integrated learning: "After "distance learning" and "blended learning", this is the era of the "integrated learning""?.

The term "Integrated Learning" was proposed by Pierre Dillenbourg to explain the current development of blended learning with complementary faceto-face teaching and distance learning, making the link between different pedagogical and technological strategies:

- integration of an educational strategy to develop both individual, group and classroom work,

- integration of classroom teaching (lecture, exercises, practical work, etc.) and distance teaching (forum, exercises, etc.), the so-called the pedagogical scenario,

- integration of different technologies,

- integration of theoretical and practical knowledge/skills.

"Therefore, instead of speaking of CSCL in such a broadened sense of the concept, we tend to use the notion of integrated learning, i.e. integration within a coherent pedagogical scenario of activities that occur across multiple social planes (individual, group and class) and places, and can be supported with multiple tools. In formal and informal learning settings, CSCL activities are embedded in more comprehensive sets of activities." (Dillenbourg, Fischer, 2007).

7 During the fourth edition of the Forum des TIC held at the Universite du travail de Charleroi (Belgium), Pierre Dillenbourg proposed, in a visioconference, an intervention provocatively entitle "The end of e-learning" ("La fin du e-learning"). 
Therefore it is necessary to talk about integrated learning to discuss learning devices bringing together face-to-face and distance modalities, such as the ones we studied.

The presentation of the field of study inevitably leads us to begin by distinguishing two frames of research: that of the learning tool and that of the elearning situation. In this sense, our approach can be described as "tooloriented", seeking to bring out the meaning of the communication through its interaction with components of the learning tools (Wilhelm, 2010). To define the term learning device or learning tool, we choose to use Georges Le Meur's definition, the "educational provision" (Le Meur, 2002):

"A learning tool can be defined as a set of services, organized in time and in space, to allow students to perform learning [...]. The online learning tools are characterized from a technological point of view by a strong digital instrumentation of the act of learning" (Ibid.: 185).

Thus, a learning (or training) tool can be considered as a set of components (in terms of resources/learning tools) available to students to learn. It is also "a body, a place of social interaction and cooperation with its intentions, its material and symbolic functioning and, finally, its own modes of interactions" (Peraya, 1999: 153).

Our research focuses on the third year Bachelor's degree, called Licence 3 in France (a National Diploma accredited by the Ministry of National Education) provided in face-to-face format (over a year), but also at a distance, as e-learning (over two years). The main difference between e-learning and classroom training lies in the components of each of the two learning systems. Classroom training is usually provided by a trainer to learners in the same specialized environment, relying on a direct teaching relationship and in a lecture mode, for a predetermined period.

The studied e-learning environment here is only open under the Continuing Vocational Training format and has a limited number of spaces for about thirty students (called student interns) and it does this because it wants to be a successful educational program in which teachers and student trainees or interns are committed ${ }^{8}$. The students engaging in such training are required to sign a learning contract between the two parties (students and teachers). By signing this document, the student intern agrees to be present at all face-to-face sessions and perform the required work in a timely manner. More symbolically, the learning agreement means the student interns are "responsible for their training": the system leads them to take responsibility for the success or failure of their training.

8 The learners have to pay for this programme. In general, businesses support them as most of the learners are employees. 
The program is based on "a specific support tool" whose components are:

- Monthly gatherings: a meeting is organized by the teaching staff every month. Students emphasize the importance of these meetings, allowing them to meet, to encourage each other, to materialize and individualize relationships.

- An educational site: a platform provides for the organization of activities and access to online resources. The intern (student) also has access to a discussion forum; these forums are free and organized by theme and everyone can participate by writing a message at any time and reading the other posts. The written and asynchronous aspects of the forum allows for the "sharing of experiences" (Develotte, Mangenot, 2004).

- Telephone tutorials: Every week, teachers (who then take the role of tutors) provide individualized assistance in answering direct questions from students. The telephone tutorials, an integral part of the learning environment, offer students the opportunity to get in touch with their teachers (synchronous mode). They can then ask any question directly, ask for help and advice.

- Online appointments ("Chat"): students and teachers have the opportunity to meet regularly to discuss and apply technological knowledge by discussing a particular topic.

All components of this learning tool allow the researchers to assume from the onset of the study that there are collective learning situations, as we shall see in the following description of the learning situation.

The actual operation of these components is what we call the learning situation. We are interested in actors and their actions, 'actual actions': what the stakeholders are doing (effective actions or informal practices), saying (remarks) and the visions they have of their actions and words (depending on how they perceive the learning tool). It is also about the ways of organizing work under the constraints inherent to their non-academic life (personal and professional constraints of the student $)^{9}$. We use "learning situation" to describe the concrete and real actions, the various components of discretionary learning that we just described. In this study, we look at "how they - the learners - do" or the actual concrete actions of the learners.

During the investigation, 19 people were registered for the course: the average age of these students is thirty years (we see a very large majority of

These factors inevitably single out the actor in a particular situation as we consider his tastes, choices and personal opinions, values, past, culture, challenges, positioning. This set of elements is what is called the system of relevance. 
women in this training: one man only per eighteen women). Half of the students ${ }^{10}$ are married, one quarter are single and the last quarter are people who are cohabiting. More than one in two has at least one dependent child. Over three-quarters of them are employees and provide various functions depending on their areas of activity: journalist, assistant manager, administrative manager in an engineering school in computer science, communication assistant in the metalworking sector, medical assistant in a pharmaceutical laboratory, a person in charge of a logistical team. They come from various educational backgrounds (Accounting and Management, Communication-advertising, Graphics, Business Communication, Services and communication networks). This description raises the primary characteristic of these students: they work while studying.

The reasons that led students to choose this type of course are very diverse and range from the fact that this type of training offers the opportunity to learn in an institution without having to move from home (and especially without having to change their personal and professional organization), an interest in the content of the training itself, the desire to grow professionally, the desire to obtain a Bachelor's Degree recognized by the state, the opportunity to be able to grow and to enrich oneself intellectually as well as the department's theoretical position.

After having identified the different student profiles and the reasons for their enrollment in distance education, we wanted to investigate their views on the relations they had with each other and with the teaching team. With these, the opinions of students ${ }^{11}$ indicate a strong need to "tame distance" (Jacquinot, 1993) and to overcome geographical distance between them: "We are really waiting for an immediate return from the teaching staff in terms of information, certainly, but also and especially in terms of relationships, support and counseling", two students noted. Indeed, since they see the pedagogical staff on very limited occasions, students say they expect ongoing support and high reactivity when sending messages to their teachers, or when asking questions during the telephone tutorials. The main criticisms of students emerge from the technical tools, and more specifically the platform, which is not as good as they would like it to be (connection problems or disconnections without apparent reasons, etc.).

However, more than half of the students surveyed said that the platform, including the discussion forum, help to maintain close relations between them, giving them the opportunity to recreate links, to comfort themselves and others,

\footnotetext{
${ }^{10}$ To be clear, we have chosen to quantify the given information, even if the sample is small.

${ }^{11}$ Three quarters of the surveyed students.
} 
to situate themselves as compared to others, to feel supported and understood by other people sharing the same learning situation ${ }^{12}$.

In addition, students also use, on a regular basis, other means of communication, especially online conversations on servers like Msn Messenger or on social networking sites like Facebook. Thus, they argue that their exchanges are more "individualized", more "discrete" and more "friendly". Just like the forum discussions, telephone tutorials are components of the course appreciated by students for availability and demonstrated commitment of tutors, for the psychological support they represent, or for the informational assistance provided.

We propose now to look back on this situation from a communicational viewpoint and thus better understand how students bridge the distance through the emergence of a learning community.

\section{Bridging the gap/distance through the emergence of a learning community}

Whatever the reasons for the student interns to choose e-learning rather than traditional classroom training, this choice is meaningful and relevant to the personal/professional projects of the actors concerned and emphasizes the indisputable motivation they have to complete their project. These student interns allow a new meaning to emerge around this action related to the choice of training; this new meaning is intrinsic to the actor himself, his challenges, his personal objectives related to his identity, his professional objectives and, finally, the objectives of his university.

Through the description of the learning tool as well as the situation of elearning, we were able to check our own postulate of the existence of collective learning situations. Indeed, whether at monthly face-to-face meetings, in their discussions on social networks or on the discussion forum, these students share their personal, psychological and academic problems but also try to create opportunities to study together outside of the framework provided by the training system (despite the distance between them). These practices emphasize a strong need to address the latent lack induced by this type of learning tool. In fact, a student can not be an isolated actor alone in the course and must be considered in interaction with others of the same learning tool. At the onset, when the learner enters the course, s/he does not know the other learners (whom s/he never meets often anyway). To counter this, the students will get to know each other through various technological media: "Education and training are

12 This is precisely why we often find, on the discussion forums, personal and/or professional information, showing inherent constraints in their learning situation. 
ways to build and assert oneself, against oneself, but also to be recognized in a community, the small community of peers and the wider community of professional and social relationships" (Glikman, 2002: 253).

Students build these relationships through the different technological tools; this is how a learning community is constructed. In this sense, the digital space "can be conceptualized as community support, shared space of the collective" (Wilhelm, 2010: 98).

In 1991, in a study conducted by Jean Lave and Etienne Wenger (Situated Learning: Legitimate Peripheral Participation), the term community of practice appears for the first time. This concept initially refers to various social groups setting up places and times allocated to learning and incoming students. They then hypothesized that learning is a process of participation in social practices, or "communities of practice". They then sought to understand the process of acquisition of knowledge/expertise in a way of belonging to social groups rather than in terms of cognitive construction. Thus the act of learning becomes a way to participate in social practice or a way of belonging to a community.

In 1998, Etienne Wenger continues his ethnographical study by developing the theory of communities of practice. He then proposed a mapping of communities of practice, including 3 features which enable these communities to be identified: mutual engagement, joint enterprise and shared repertoire. Mutual commitment ensures the existence of shared practice and points to ordinary relationships between members of a community within a social entity (which we found in our study, especially during the observation of the face-toface sessions).

The joint enterprise is between what the organization requires in terms of objectives and activities and what the role players actually do in the organization.

Finally, the shared repertoire refers to tools (documents, etc.), gestures, codes, routines even becoming elements of practice (as we have observed in the analysis of the conversations on the discussion forums in particular).

As such, students say they can refer to other students who share the same problems, the same needs, and have the same definition of the learning situation: "We know it is not enough to develop communication tools for people to communicate, but it is important that they can co-build a dynamic exchange" (Paquelin, in Le Meur, 2002: 181, our translation). The observations made in the discussion forum and the outspoken freedom of speech observed lead us to analyze this collective exchange approach as an emerging trend within a learning community.

Many authors from the field of educational technology have analyzed the different types of online communities to highlight classifications or typologies. Thus, France Henry and Beatrice Pudelko (2006) define four types of virtual 
communities: the community of interest, the community of intellectual interest, the community of learners and the community of practice. According to their definitions, the community of learners that we present here corresponds to a community of practice characterized by the identification of the flow of knowledge, mutual assistance, exchange of information, building relationships, sharing of know-how.

Scientific literature on the concept of community establishes distinction and demarcation levels of practices, according to the strength of the social ties developed between the community members and the didactic intent (Henry Pudelko). Thus the notion of community of practice can sometimes be used in conjunction with other theories such as epistemic communities (Hass, 1992), professional communities (Vaast, 2002) or virtual communities (Rheingold, $1995)^{13}$.

While initially the communities, in the traditional sense of the term, are characterized by a certain geographic proximity $^{14}$, the virtual learning communities compensate for this distance through sharing of common interests, common projects, but also common values. Without a doubt, in the present study, the creation of this learning community is facilitated by the participants' own cultural and identity backgrounds ${ }^{15}$ : "For there to be a sense of belonging to a community, the scene of the interactions (in face-to-face or electronically) must bring together to persons who own or build common bonds between them and whose interactions are reciprocal, sustained, long lasting" (Proulx, 2004: 4).

Indeed, these commonalities undoubtedly facilitate the establishment of common and ritualized type of frequent informal conversations outside the university with other means of communication than those available to them in the learning device (conversations via Msn or Facebook) as we have seen in our research.

By engaging in this course, students sign a learning agreement; this demand for commitment reflects an autonomous operating injunction (Wilhelm, 2010) made by the learning device. Especially as we have seen in the analysis of conversations on the discussion board, students try to recreate a true learning community, transcending the boundaries of distance in their training by finding cues and spaces of acceptance in this new device training, instilling a group

${ }^{13}$ It is also worth noting that some researchers and theorists radically question the very notion of community developed by Lave and Wenger in particular: we think of James Gee who, in 2005, proposed the notion of "affinity space", but the present paper chooses not to develop this theory.

${ }^{14} \mathrm{We}$ refer to the notion of territorial anchoring of a community.

15 As such, it should be noted that virtual communities may reflect a social structure reproducing some characteristics of the structure, rules, norms, implicit or explicit codes of conduct, sanctions of a face-to-face society. 
dynamic, thus overcoming latent loneliness (students work remotely). In doing so, they remind everyone that they have the same goal of a successful training, and they must help each other, regardless of how they operate and consider the various components of the device.

Christine Develotte and François Mangenot cite Barry Wellman, who, in 2001, defines learning communities as follows: "Communities are networks of relationships between people who contribute to conviviality, help, information, a sense of belonging and social identity" (Develotte, Mangenot, 2004, our translation). This definition takes into account the socio-emotional dimension, as well as the cognitive and stresses the importance of social ties, particularly through the "help" that can be given by tutors.

Through these means of communication, students can then overcome the problem of the distance between them, "tame the distance and delete the absence" (Jacquinot, 1993).The spontaneity of online interactions in small groups of learners [...] having a common activity and animated appropriately produces a feeling of closeness and solidarity between students and a spirit of cooperation and mutual encouragement. A familiarity between online learners is thus created, despite the age, culture, initial training and professional differences, despite the distance or thanks to it and the differences between the learners. And in this climate of sympathy, spontaneity and mutual support, the relationships of the online learners with their trainer quickly lose their hierarchical nature (Bates, 1995: 209-210, quoted by Develotte and Mangenot, 2004: 331). Students try to move beyond the boundaries of distance; they have to find back references in this new learning environment, to instill group dynamics, thus overcoming latent loneliness (of the student in an e-learning environment). The creation of this learning community (virtual or real) becomes a challenge for each of them, placing them in a collective intellectual practice and inspiring a motivational dynamic of participation ${ }^{16}$.

We speak of a collective approach to knowledge sharing to the extent that we observe that these student interns share their responses to their difficulties, as well as their knowledge. This idea of collaboration allows them to reach a common goal, a common interest, namely the successful completion of the course, or more concretely work together on a joint project to submit thereafter (group work).

Thus, students have completely transformed their relationship to knowledge, now evolving into a whole new work environment, with practices

16 This social phenomenon is at the heart of the dialectical process that Wenger called "participation" and "reification": by participating, each member of the group seems to be involved in this community and the meaning given to this action becomes that of identity construction (Wenger, 1998). 
very different from the traditional face-to-face set-up. The insertion of an information tool within the learning environment leads the learners to change their environment; learning is more of self-centered, autonomous and brings learner empowerment.

\section{Conclusion}

The presentation of an e-learning course in communication and information sciences has enabled us to highlight some of the meaningful learning experiences for students using the learning tool. In particular, we found that loneliness - very present in the training - induced the emergence of a learning community, with students venturing on a collective and shared path. This understanding of the stakeholders' views in a learning situation is only possible given the meaning that each student gives to his/her learning situation, experiencing and interacting with other components of the course (be these human entities, material or ideational).

This study highlighted that students were forced to change their position of learning alone at a distance to that of a learner belonging to a learning community. Their respective behaviors in the group then take on new meanings, revolving mainly around identity recognition of shared interests and objectives (to the extent they deal with other students sharing the same situations, needs, issues, problems, and thereby the same meaning).

We can then assume that the creation of this community is a way for them to move beyond the virtual group and to project, in an imaginary or symbolic way, social and relational characteristics inherent to any physical and real community. It now remains to be examined what the scope, importance or social and cultural engagement, of such communities can be in the implementation of social projects.

\section{Bibliography}

Choplin, H., (dir.), Les TIC au service de nouveaux dispositifs de formation - Éducation permanente, $\mathrm{n}^{\circ} 152,2002$.

Depover C., Giardina M., Marton P., Les environnements d'apprentissage multimédia, Paris, l'Harmattan, 1998.

Develotte C., Mangenot F., «Tutorat et communauté dans un campus numérique non collaboratif », Distances et savoirs, vol. 2, n 3, 2004, p. 309-333.

DILlENBOURG P., FISCHER F. «Basics of Computer-Supported Collaborative Learning », Zeitschrift für Berufs- und Wirtschaftspädagogik. 21, 2007, p. 111-130.

Glikman V., Des cours par correspondance au "e-learning», panorama des formations ouvertes et à distance, Paris, Presses Universitaires de France, 2002. 
Jacquinot G., «Apprivoiser la distance et supprimer l'absence ? Ou les défis de la formation à distance », Revue Française de Pédagogie, Paris, INRP, n 102, 1993, p. 55-67.

LAVE Jean, WENGER Etienne, 1991, Situated Learning: Legitimate Peripheral Participation, Cambridge, Cambridge University Press.

Legendre R., Dictionnaire actuel de l'éducation, $3^{\text {ème }}$ édition, Montréal, Éditions Guérin, 2005.

Le Meur G., (dir), Université ouverte, formation virtuelle et apprentissage : communications francophones du cinquième Colloque européen sur l'autoformation, Paris, l'Harmattan, 2002.

Le Moigne J.-L., Le constructivisme. Modéliser pour comprendre, Tome 3, Paris, l'Harmattan, 2003.

Lévy P., Intelligence collective, Paris, La Découverte, 1994.

Mangenot F., «Analyser les interactions pédagogiques en ligne, pourquoi, comment?» Intercompreensão, 13 (décembre 2006), Comunicacão electronica em contextos de educacão linguistica. Teorias e praticas, p. 11-28. Editions Cosmos/Escola Superior de Educacão de Santarem, Portugal.

Matthey M., Apprentissage d'une langue et interaction verbale, $2^{\text {ème }}$ édition, Bern : Peter Lang, 2003.

Mucchielli A., (dir), Dictionnaire des méthodes qualitatives en sciences humaines, Paris, Armand Colin, 2004.

Mucchielli A., (dir), « La place du constructivisme pour l'étude des communications », Actes du colloque de Béziers, Béziers, Centre d'étude et de recherche sur l'information et la communication, Avril 2003.

Mucchielli A., «Un nouveau domaine des sciences info-com : la formation à distance », Distances et savoirs, vol. 4, $\mathrm{n}^{\circ}$ 2, 2006, p. 223-229.

Papadakis M. C., People Can Create a Sense of Community in Cyberspace, Revue en ligne, Arlington, SRI International, 2003, URL: www.sri.com/policy/csted/reports/sandt/it/Papadakis IT virtual communities issue brief.pdf consulté en février 2010.

Parsons T., Schütz A., The Theory of Social Action, Bloomington, Indiana University Press, 1978.

Peraya D., Médiation et médiatisation : le campus virtuel. Le dispositif. Entre usages et concepts, in Jacquinot G., Montoyer L., (dir.), Le Dispositif. Entre usage et concepts, Hermès, CNRS, n 25, 1999, p. 153-167.

Perret-Clermont A.-N., La Construction de l'Intelligence dans l'Interaction Sociale, Genève, Peter Lang, 1979.

Proulx S., «Les communautés virtuelles construisent-elles du lien social ? », Actes du colloque L'organisation média. Dispositifs médiatiques, sémiotiques et de médiations de l'organisation, Université Jean Moulin, Lyon, 19-20 novembre 2004, 8 p.

Resnick, L.B., Levine J.M., Teasley S.D., (eds.), Perspectives on Socially Shared Cognition, American Psychological Association, Washington, D.C., 1991, p. 1-20.

Szafrajzen B., Lecture communicationnelle de deux dispositifs d'apprentissage au sein d'un même département universitaire. Le cas de la licence en sciences de l'information et de la communication, thèse de doctorat, Université de Montpellier, 2010.

Thiétart, R.A., Méthodes de recherche en management, Gestion Sup, Dunod, 2007. 
Watzlawick P., (dir), L'invention de la réalité. Contributions au constructivisme, Paris, Seuil, 1988.

Weick, K. E., Sensemaking In Organizations, Thousand Oaks : Sage, 1995.

Wenger E., Communities of Practice: Learning, Meaning and Identity, New York, Cambridge University Press, 1998.

Wilhelm C., «Emergence d'une culture communicationnelle au sein d'un dispositif international en ligne, Distances géoculturelles et proximité axioliogique », Distances et savoirs, $\mathrm{n}^{\circ}$, vol. 8, 2010, p. 79-107. 